\title{
Yeniden Yapılanma Sürecinde Olan Türkiye Cumhuriyeti Devlet Demiryollarında Hizmet Kalitesi
}

\section{The Improvements on Service Quality of Turkish Railway Corporation (TCDD) in the Process of Reorganization}

\section{Doç. Dr. Mine Şenel - Yrd. Doç. Dr. Bilgin Şenel - Prof. Dr. Belkıs Özkara}

\section{Öz}

$\mathrm{Bu}$ çalışma, yeniden yapılanma sürecinde olan TCDD’na ilişkin algılanan hizmet kalitesi düzeyinin incelenmesi amacıyla gerçekleştirilmiştir. Bu bağlamda hizmet kalitesinin müssterilerin demografik özellikleriyle ilişkisi incelenmiş ve 2004 yllında yapılan TCDD hizmet kalitesi ölçümleriyle sonuçlar kıyaslanmıştır. Algilanan hizmet kalitesi, Parasuraman, Zeithaml ve Berry tarafindan geliștirilen ve literatürde siklikla kullanılan SERVQUAL ölçeği ile incelenmiştir. Verilerin toplanması birincil kaynaklardan oluşturulan anket formuyla sağlanmıştır. Katılımcılara TCDD tarafından verilen hizmetlere ilişkin, çeşitli yargılar verilmiş ve her bir ifadeyi beklentileri ve alguladikları şeklinde derecelendirmeleri istenmiştir. Strastyla verilerin analizini güvenilirlik, ortalamaların hesaplanması, bağımsiz t-testi ve ANOVA (tek yönlü varyans analizi) tekniği oluşturmaktadır. Elde edilen veriler kullanılarak, katılımcılar için hizmet kalitesinin beş boyutu arasında en önemli görülen boyutun ve en çok geliştirilmesi gereken boyutun belirlenmesi için analiz gerçekleştirilmiştir. Sonuçlarda 2004-2010 arasında yapılmış olan yatırımlar doğrultusunda her bir boyutta hizmet kalitesi açısından gelişmelerin olduğu görülmektedir. Ancak hala bu iyileştirme çalışmalarının yeterli olmadiğı ve müşterilerin beş boyutta beklentilerini yakalayabilmenin gerekliliği ortaya konulmuştur.

Anahtar Kelimeler: Hizmet Kalitesi, SERVQUAL, TCDD, Yeniden Yapılandırma

\begin{abstract}
This study has been conducted to assess the perceived service quality of Turkish Railways Corporation (TCDD), which is in the process of reorganization. For achievement of the purpose of the study, the relationships between service quality and demographic characteristics of customers have been examined and the results have been compared to the service quality measurements done in 2004. Perceived service quality is measured using widely accepted SERVQUAL scale that is developed by Parasuraman, Zeithaml and Berry. Data has been collected from primary sources. Respondents have been given the statements in proportional way. Data analysis is performed by reliability checks, computation of means, $t$-test for independent samples and finally ANOVA (Analysis of Variance). Using the results, the most important dimension for respondents is selected among the five dimensions of service quality. It has been observed that there are meaningful improvements in the each of service quality dimensions from angel of the amount of investments. However, it is also seen that the improvements are not enough and customers expect more than current service quality in all the dimensions of service quality.
\end{abstract}

Keywords: Service Quality, SERVQUAL, TCDD, Reorganization

Doç. Dr. Mine Şenel, Anadolu Üniversitesi Mühendislik Fakültesi, minesenel@tunceli.edu.tr Yrd. Doç. Dr. Bilgin Şenel, Anadolu Üniversitesi Mühendislik Fakültesi, bilginsenel@tunceli.edu.tr Prof. Dr. Belkıs Özkara, Afyon Kocatepe Üniversitesi İİBF, bozkara@aku.edu.tr 


\section{Giriş}

Son ylllarda, küreselleşmenin de etkisiyle demiryolu yolcu taşımacilığında büyük değişimler gerçekleşmekte ve gerek iş, gerekse turistik amaçlı yapılan seyahatlerde artış görülmektedir. Sektörün gelişimi ve kendini yenileme aşamalarında yapılan yatırımların geri dönüşümünü sağlamak için müşteri memnuniyeti ve sunulan hizmet kalitesi kilit rol oynamaktadır. Yolcu taşımacılığında alternatif ulaşım olanaklarının var olması sektörü, sürekli kendini yenilemeye ve dinamik rekabet ortamında var olma savaşı vermeye mecbur bırakmaktadır. Bu nedenle, ülkemizde demiryolu sektöründe en büyük kurum olan TCDD de yeniden yapılanma sürecine girmiştir.

Fakat TCDD yollarının da bir kamu kuruluşu olduğu düşünüldüğünde ve kamu yönetimi anlayışındaki mal ve hizmetlerden yararlanan kimselere "müşteri" gözüyle değil "vatandaş" gözüyle bakılmasının yeniden yapilanma sürecinin önündeki en önemli engel olduğu söylenebilir. Ek olarak TCDD yolları yeniden yapılanma sürecinde kamu yönetiminin sorunları d1şında kamu ekonomisinin işleyişinden kaynaklanan ciddi sorunlar da (enflasyon, bütçe açıları, işsizlik, gelir dağılımındaki adaletsizlik vs. sorunlar temelde devletin ekonomiye olan müdahalesi) engelleyici unsurlardan bir diğeridir. Ülkemizde kamu yönetimi ve kamu ekonomisinde yaşanan sorunları ortadan kaldırmak için kapsamlı bir reformun yapılması gereklidir. Böylece kamu sektöründe mevcut organizasyon yapısının, faaliyetlerin ve tüm süreçlerin yeniden düşünülmesi, yeniden tasarlanması ve yeniden yapılandırılması en önemli adım olacaktır. Aksi halde, yeni rekabet şartlarına uyum sağlamak konusunda zaaf gösteren organizasyonların yaşama şansları düşüktür (Coşkun, 2001: 689-690). Bu noktada Türkiye'de en büyük kamu işletmesi olan TCDD yollarının yeniden yapılanma sürecinde hızlı ve teknolojik yatırımları yapabilmesi, yönetim anlayışında, geleneksel kamu anlayışından farklı olarak esnek yönetim anlayışıyla yönetilmesi diğer kamu kuruluşlarına örnek olacaktır

Genel olarak yeniden yapılanma; Rekabet gücünü arttırarak hayatta kalabilmek, daha fazla kar etmek ve sürekli bir gelişme temposu içerisine girebilmek için bir işletmenin hızla değişen dünya şartlarına ayak uydurmak üzere, kendisini fiziki ve psikolojik alanlarda baştan aşağı yeniden düzenlemesidir (Çetin, 1996). Diğer bir tanımda yeniden yapılanma; maliyet, kalite ve hizmet gibi performans ölçütlerinde önemli gelişmeler elde etmek için iş süreçlerinin yeniden düşünülüp ve yeniden tasarlanmasıdır (Hammer ve Champy, 1993). Dünya'da yeniden yapılanma hem özel sektör hemde kamu sektöründeki yöneticilerin sıklıkla başvurdukları yönetim tekniklerinden biridir. Çünkü işletmeler, değişen çevre koşulları ve işletme stratejileri doğrultusunda ürün ve hizmetlerin kalitesini arttırmak, maliyetleri azaltmak, müşteriye daha yakın olmak, teknolojideki gelişmelerden daha fazla yararlanmak gibi gerekçelerle yeniden yapılanma çalışmalarına yönelmektedirler. Yöneticilerin sıklıkla başvurdukları yeniden yapılanma süreci dört adımdan oluşmaktadır. İlk adım, işletmenin yeniden yapılanması, ikinci adım işletmenin yeniden düzenlenmesi, üçüncü adım örgütsel süreçlerin yeniden dizaynı, dördüncü adım ise, organizasyonun daha dinamik, yaratıcı, esnek hale getirilmesidir.

TCDD yollarının da bir kamu kuruluşu olduğu dikkate alınırsa, kamu yönetimi anlayışındaki mal ve hizmetlerden yararlanan kimselere "müşteri" gözüyle değil "vatandaş" gözüyle bakılmasının yeniden yapılanma sürecinin önündeki en büyük engel olduğu söylenebilir. Kamu yönetiminin diğer genel sorunları da (enflasyon, bütçe açıkları, işsizlik, gelir dağılımındaki adaletsizlik vs.) TCDD yollarının yeniden yapılanma sürecini engelleyici unsurlardır. Ülkemizde kamu yönetimi ve kamu ekonomisinde yaşanan sorunları ortadan kaldırmak için kapsamlı bir reformun yapılması gereklidir. Böylece kamu sektöründe mevcut organizasyon yapısının, faaliyetlerin ve tüm süreçlerin yeniden düşünülmesi, yeniden dizayn edilmesi ve yeniden yapılandırılması önemli bir adım olacaktır. Aksi halde yeni rekabet şartlarına uyum sağlamak konusunda zaaf gösteren organizasyonların yaşama şansları düşüktür (Coşkun, 2001;689-690). Bu noktada Türkiyede en büyük kamu işletmesi olan TCDD yollarının yeniden yapılanma sürecinde hızlı ve teknolojik yatırımları yapabilmesi, yönetim anlayışında geleneksel kamu anlayışlarından farklı olarak esnek yönetim anlayışına yöneltilebilmesi diğer kamu kuruşlarına örnek olacaktır.

Yeniden yapılanma sürecinde yönetimin başarısı, tüketici tatmini tabanında ölçülmektedir (Reschenthaler, 1996:133). Donelly ve arkadaşları (1996) tüketici tatmininin, hizmet kalitesi ölçüm tekniği olarak SERVQUAL ile ölçümünün kamu yönetimlerinde uygulanabilirliğini incelemişlerdir. $\mathrm{Bu}$ incelemeler sonucunda akademisyenler, hizmet kalitesi ile vatandaş tatmininin birbirleri yerine kullanılabileceğini ifade etmektedirler (Reeves vbe ark, 1995:63). Litera- 
tür incelendiğinde yeniden yapılanma ve başarısının tüketici tatmini ile ölçülmesi noktasında özel sektörde olduğu gibi (Ruhli, Treichler and Schmidt, 1995; Stoddard; Jarvenpaa, Littlejohn, 1996; Davis, J and Mehta, 1997; Beugre, C. D, 1998; James, Chee-Sing, Kin-Lee, 2000; McNulty, 2002), kamu sektöründe de yapılmış çalışmalar mevcuttur (Libbey, 1994; Halachmi, 1996; Halachmi and Bovaird, 1997; McAdam and Mitchell, 1998; Gulledge, Sommer, and Rainer, 2002; Ongaro, 2004; Mihyar, 2007; Mihyar, Ameed and Samak, 2007; Zaher, Mushtag and Ishaq, 2008).

Bu çalışmada, Reeves ve ark (1995) ve Donelly ve arkadaşlarının (1996) çalışmaları temel alınarak yeniden yapılanma sürecinde olan TCDD yollarında 2004 ve 2010 yıllarında yapılan müșteri tatmini (Hizmet Kalitesi) ölçüm sonuçları karşılaştırılarak TCDD yolları yönetiminin başarı ve başarısız olup olmadıkları ortaya konulmaya çalışılmaktadır.

\section{Hizmet ve Hizmet Kalitesi}

İnsanla doğrudan ve dolaylı olarak ilgili her konuda hizmetten söz edilebilir. Dolayısıyla çok değişik türde ve nitelikte hizmetle karşılaşıllır. Bütün bu hizmet türlerini kapsayacak tek bir tanım yapmak oldukça güçtür.

Avrupa Birliği açısından hizmet, Roma Antlaşmasının 60. maddesinde ifade edildiği gibi , normal olarak ücret karşılığında yapılan ve malların, sermayenin ve kişilerin serbest dolaşımı kapsamına girmeyen işler olarak tanımlanmaktadır(Bektaş, 2005,s. 3-4). Colliere göre hizmet; üretildiği yerde tüketilen bir iş veya eylem, bir performans, sosyal olay yada çaba'dır (Uyguç 1998,s. 8). Lovelock (1991), hizmeti; bir şey (nesne) değil, bir süreç yada performans olarak tanımlamıştır(Özer ve Özdemir, 2007,s.11). Kotler da hizmetleri; bir tarafın diğer bir tarafa sunduğu soyut ve herhangi bir somut bir şeye sahip olmakla sonuçlanmayan bir faaliyet olarak tanımlamıştır (Dinçer, 1998,s.434).

Bu tanımlardan da anlaşıldığg gibi hizmetlerin mallardan ayrılan çeşitli özellikleri vardır. Hizmetlerin temel özellikleri olan soyutluğu hizmetin yaratıldığ ve sunulduğu zamanın ayrılmaması olarak tanımlanan ayrılmazlığı, değişkenliği ve dayanıksızlığı, hizmet kalitesi ile ilgili yapılacak tanımları güçleștirmektedir (Kotler, 1980,s.624, Parasuraman et al,1985,s.42,
Dinçer,1998: 434; Mucuk, 1994,s.320-322). Hizmet kalitesi hizmetin yerine getiriliş kolaylığı, hizmet sunanların nezaketi, haberleşme araçlarının açıklığı, çalışanların görevlerindeki uzmanlıkları ve empati yetenekleri, hizmetin müşteri gereksinmelerine ne ölçüde cevap verdiği, hizmet sayesinde elde edilen sonuçların kalite ve çabukluğu ile ilgili bir kavramdır (Özkul, 2007)

En genel haliyle hizmet kalitesi "müşteri beklentilerinin tatmin edilmesi ya da karşılanması" şeklinde tanımlanabilir (Aydın, 2007,s.262) Hizmetlerin soyut unsurlar olması ve değerlendirilmesinin oldukça zor olması, hizmet kalitesi yerine algılanan hizmet kalitesi teriminin kullanımını gerektirmiştir (Özkul, 2007)

Castleberry ve Mclntyre (1993) algilanan hizmet kalitesini "hizmetin mükemmellik derecesi ile ilgili inanıştır" şeklinde tanımlamışlardır (Quester ve Romanjuk, 1997,s.181) . Zeithaml’a göre algılanan hizmet kalitesi "tüketicinin hizmetin üstünlüğü veya mükemmelliği hakkındaki yargısıdır" (Parasuraman et al., 1988,s. 15, Alakavuk, 2007,s. 332). Algilanan hizmet kalitesi nesnel kaliteden farklıdır. Algılanan hizmet kalitesi, müşterilerin hizmetten beklentileri ile aldıkları hizmetin performansının(algılarının) karşılaştırılması sonucunda oluşan tatmindir (Cronin and Taylor,1992,s.56; Parasuraman et al.,1988,s. 15).

Bu yaklaşımlardan hareketle, hizmet kalitesi, müşterinin hizmeti satın aldıktan sonra o hizmetten sağladıklarının kendisinde yarattığı duygu olup, söz konusu hizmetten ne kadar tatmin olup olmadığını ifade etmektedir. Dolayısıyla hizmet kalitesi kavramının bileşenlerini şu şekilde sıralamak mümkündür(Aydın, 2007, s. 263):

- Alıcının gereksinimi ve beklentileri

- Bunların doğrultusunda hizmette olması gereken özellikler

- Hizmetin bu özellikler ve niteliklere sahip olma derecesi.

Hizmetlerde kalitenin değerlendirilmesi ve hizmetlerde sonucun ölçülmesi çok kolay değildir (Brown et al., 1991, s.240; Carman, 1990,s.33; Parasuraman et al., 1985,s.42, 1988,s.13; Peyrot, Cooper and Schnapf, 1993,s.24). Hizmetteki gelişmenin ölçülmesi, gözlenmesi ve kontrolü soyut olmasindan dolayı zordur. Müşterisini memnun ettiğini düşünen bir işletme di- 
ğer işletmelerin daha iyi daha cazip hizmetleriyle müşteri kaybedebilir. Çünkü hizmette mükemmelliğin mallarda olduğu gibi net bir sinırı yoktur. Hizmetlerin anında sunulması ve her şeyin müşterinin gözünün önünde meydana gelmesi faaliyetlerin son kontrolünü yapmayı engellemektedir. Bu nedenle faaliyetlerin ilk defada doğru bir şekilde yapılması, iş görenlerin davranışlarının da önceden kontrol edilemeyeceği gerçeği düşünüldüğünde hizmet kalitesinin sağlanmasında önem kazanmaktadır (Aydın, 2007,s. 264).

Hizmet kalitesini ölçme konusundaki tüm güçlüklere rağmen literatürde Caruana ve Pitt tarafından geliştirilen INTQUAL, Cronin ve Talyor'un SERVPERF ve Parasuraman, Zeithaml ve Berry'nin SERVQUAL'i gibi çeşitli kalite ölçme yöntem ve modellerine rastlanmaktadır. Bu çalışmada hizmet kalitesi ölçümü için literatürde yaygın olarak kullanılan 5 kalite boyutu (Fiziksel Özellikler, Güvenilirlik, Heveslilik, Güven, Empati) ve 22 maddeden oluşan SERVQUAL ölçeği kullanılmıştır(Anderson ve Zwelling, 1996,s. 9-22; Anderson,1995,s. 32-37, Peyrot ve Cooper ve Schnapf, 1993,s. 24-33; Kilbourne ve Duffy vd, 2004,s.524533). Zeithaml, Parasuraman ve Berry hizmet kalitesinin ölçülmesindeki tek ölçütü, sunulan hizmetin tüketicinin kaliteden beklentisine uygunluğu olarak belirlemiş, yani hizmette kalitenin tanımının tüketici tarafından belirlendiğini ileri sürmüşlerdir. Hizmet sektöründe tüketici yalnızca hizmetin kalitesini değil aynı zamanda sınırlarını da belirlemektedir. $O$ halde hizmetin kalitesi ve sınırları müşteri odaklıdır.

\section{Servqual Ölçeği}

Algılanan hizmet kalitesini sayısal temelde ölçmek için, Parasuraman, Zeithaml ve Berry yaptığ tırmalarında, Servqual ölçeğini geliştirmişlerdir. Söz konusu ölçek iki kısımdan meydana gelmektedir. Birinci kısımda belli bir hizmet sektörü için tüketicilerin beklentilerini ölçmeye yönelik ifadeler yer almakta, ikinci kısımda ise tüketicilerin belli bir hizmet sektöründeki belli bir işletmenin hizmetleri hakkındaki algılarını ölçmeye yönelik ifadelere yer verilmektedir. SERVQUAL ölçeğinde kullanılan Likert tipi ölçekte 7 rakamı "kesinlikle katılıyorum" yargısını, 1 rakamı ise "kesinlikle katılmıyorum " yargısını ifade etmektedir. Algilanan hizmet kalitesi, beklenen hizmet ve alg1lanan hizmet arasındaki fark olduğundan, araştırmac1lar algilanan hizmet kalitesini:

\section{Algılanan Hizmet Kalitesi $(\mathrm{Q})=$ Algılanan Hiz- met $(\mathrm{P})$ - Beklenen Hizmet $(\mathrm{E})$}

şeklinde formüle etmişlerdir.

$\mathrm{Bu}$ yolla her bir soru önermesi için SERVQUAL skoru hesaplanmaktadır. Her bir soru önermesine 7'li Likert ölçek üzerinden beklenti maddeleri ve algılama maddelerine verilen puanların karşılıklı olarak farkının alınmasıyla, her bir soru önermesi için -6 ile +6 arasında değişen SERVQUAL skorları hesaplanmaktadır. Servqual skorunun pozitif bulunması, müşteri beklentilerinin aşıldığ 1 anlamına gelmekte, dolayısıyla müşterilerin aldıkları hizmete yönelik kalite algısının yüksek olduğu yorumu yapılabilmektedir. Servqual skorunun negatif olması durumunda, müşteri beklentilerinin karşılanmadığı, dolayısıyla o kurumun hizmetlerine yönelik kalite algısının düşük olduğu anlamına gelecektir. Servqual skorunun sıfır olması durumunda ise, müşteri beklentilerinin en azından karşılandığı, dolayısıyla algılanan hizmet kalitesinin tatminkar olduğu sonucu çıartılabilir.

Servqual ölçeği, genel olarak tüm hizmet sağlayan organizasyonlarda geçerli olan aşağıdaki beş hizmet kalitesi boyutundan oluşmaktadır. Bu boyutlar aşağıda gösterilmektedir:

- Fiziksel Özellikler (Tangibles): hizmet sunan kurumun fiziksel olanakları, araç gereç ve personelin görünüşü,

- Güvenilirlik (Reliability): Kurumun söz verilen hizmeti doğru ve güvenilir bir şekilde yerine getirebilme yeteneği,

- Heveslilik (Responsiveness): Kurumun yardım etme ve hizmeti hızlı bir şekilde verme isteği,

- Teminat (Assurance): Kurum çalışanlarının bilgili ve nazik olması ve müşterilerde güven duygusu uyandırabilme becerileri,

- Empati (Empathy): Kurum personelinin kendisini müşterinin yerine koyması ve müşteriye kişisel ilgi gösterilmesi (Mangold \& Babakus, 1992; Parasuraman et al., 1988).

Bu çalışmada kullanılan SERVQUAL ölçeğinin boyutları ve her bir boyuta düşen soru sayısı Tablo 1 de gösterilmektedir. Servqual ölçeğindeki 5 boyut ve 
22 madde ile demir yolları hizmetleri doğrultusunda tarafımızca eksik kaldığı görülen 6 madde daha eklenerek önerme sayısı 28'e çıkarılmıştır. TCDD trenlerinin genel durumu hakkındaki üç gösterge fiziksel özellikler boyutuna (Tuvaletler, Klima ve Kompart1man düzeni) eklenmiştir. İki gösterge (Lokanta çalışanları ve Temizlik Görevlileri) empati boyutuna ve bir göstergede güvenilirlik boyutuna (Kompartıman sarsintıs1) eklenmiştir.

Tablo 1. Çalışmada Kullanılan Hizmet Kalitesi Boyutları
ve Her bir Boyuta Düşen Soru Maddeleri

\begin{tabular}{|l|l|}
\hline Boyutlar & $\begin{array}{l}\text { Her } \\
\text { Düşen } \\
\text { Maddesi }\end{array}$ \\
\hline Fiziksel Ozellikler & $1-7$ \\
\hline Güvenilirlik & $8-13$ \\
\hline $\begin{array}{l}\text { Heveslilik } \\
\text { (İsteklilik) }\end{array}$ & $14-17$ \\
\hline Güven & $18-21$ \\
\hline Empati & $22-28$ \\
\hline
\end{tabular}

\section{Araştırmanın Amacı ve Hipotezi}

$\mathrm{Bu}$ çalışma, yeniden yapılanma sürecinde olan TCDD’ye ilişkin algılanan hizmet kalitesi düzeyinin incelenmesi amacıyla gerçekleştirilmiştir. Çalışmanın alt amaçlarını, hizmet kalitesinin müşterilerin demografik özellikleriyle ilişkisinin incelenmesi ve 2004 yılında yapılan TCDD hizmet kalitesi ölçüm sonuçlarıyla bu çalışmanın sonuçlarının kıyaslanması oluşturmaktadır.

Bu çalışmanın hipotezi "2004-2010 yılları arasında yapılan iyileştirme yatırımları müşterilerin algıladıkları hizmet kalitesinde olumlu gelişmeler sağlamaktadır" şeklinde oluşturulmuştur.

\section{Araştırmanın Yöntemi}

Çalışmanın amacını gerçekleştirmeye yönelik veriler anket formu ile toplanmıştır. Çalışmada orijinal 7’li Likert ölçeği yerine 5 'li likert ölçeği kullanılmıştır. Çalışmaya başlamadan önce yapılan ön incelemede orijinal anketteki negatif ve pozitif soru ifadelerinin birlikte kullanılmasının katılımciların soruları anlamasında güçlüklere ve cevaplamada yanlışlıklara neden olduğu tespit edilmiştir. Bu yüzden orijinal ankette negatif ifadeler pozitif ifadelere dönüştürülmüştür.
Bu anket Eskişehir Tren Garında, Eskişehir İzmir-Ankara Mavi Tren seyahatini 01.09.2010 ve 20.10.2010 tarihleri arasında gerçekleştirmiş ve kolayda örnekleme tekniği ile belirlenmiş müşterilerce yanıtlanmıştır. Anket, 2004 yılında Poyraz, Taşkın ve Kara tarafından İzmir-Eskişehir-İzmir Mavi Tren yolcuları ile yapılan "Demiryolları İşletmesinde Müşteri Tatmininin Ölçülmesi ve Bir Uygulama" çalışmasında kullanılan anket sorularına benzer 3 grup sorudan oluşturulmuştur. İlk grup katılımciların demografik özelliklerinin belirlenmesine yöneliktir. İkinci grup katılımcıların genel olarak TCDD'den beklentilerinin ne olduğunun sorgulanmasıyla ilgilidir. Burada katılımcıların kendi idealinde oluşturduğu demiryolu hizmetini göz önüne alması ve bu ideal duruma göre sorulara cevap vermesi istenmiştir. İkinci aşamada ise yine aynı müşterilerin hizmet aldıkları TCDD ile ilgili olarak algıladıkları performansın ne olduğu sorularına cevap vermeleri istenmiştir. Üçüncü grupta ise hizmet kalitesi boyutlarının önem dereceleri sorulmuştur. Ayrıca bu soruların dişında bir de aynı katılımcilara genel olarak TCDD hizmeti ile ilgili olarak tatmin derecelerinin ne olduğu sorulmuştur.

\section{Örnekleme Yöntemi}

Araştırmada, Eskişehir Gar binasındaki herkes dahil edildiği için kolayda örnekleme tekniği kullanılmıştır. Araştırmanın ana kütlesini Eskişehir Gar binasında İzmir-Ankara Mavi Treni kullanmış olan müşteriler oluşturmaktadır. Araştırmaya Kolayda Örnekleme tekniği kullanılarak seçilen 400 kişi (müşteri) dahil edilmiştir.

\section{Verilerin Analiz Yöntemi}

Toplanan verilerin değerlendirilmesi SPSS 16 paket programı kullanılarak yapılmıştır. Sırasıyla verilerin analizini güvenilirlik, ortalamaların hesaplanması, bağımsız t-testi ve ANOVA (tek yönlü varyans analizi) tekniği oluşturmaktadır.

$\mathrm{Bu}$ çalışmada algılanan hizmet kalitesinin ölçümü için SERVQUAL ölçeği ulaşım sektörüne uyarlanarak kullanılmıştır. Katılımcılara aldıkları hizmetlere ilişkin çeşitli yargılar verilmiş ve her bir ifadeyi beklentileri ve buldukları şeklinde derecelendirmeleri istenmiştir. Derecelendirmede; " 1 " çok düşük, " 5 " ise çok yüiksek düzeyi ifade etmektedir. SERVQUAL ölçeği, fark esasına dayalı olarak incelenmiştir.

Her bir boyut için fark esasına dayalı hizmet kalitesi (Gap-based) aşağıdaki eşitlikte ifade edildiği gibi hesaplanmaktadır (Lee ve ark., 2004). 
$G S Q_{i}=\frac{\sum_{i=1}^{n}\left(P_{i j}-E_{i j}\right)}{n_{i}}$

Burada;

$P_{i j}=$ j. boyuttaki i. özellik için hizmetin algılanan düzeyini,

$E_{i j}=\mathrm{j}$. boyuttaki i. özellik için hizmetin beklenen düzeyini,

$n_{i}=$ gözlem sayısını

göstermektedir.

\section{Bulgular ve Değerlendirmeler}

\section{Demografik Özellikler}

Demografik değişkenlere ilişkin bulgular Tablo 2' de verilmektedir.

Tablo 2'den de görüldügüü gibi seyahatlerinde TCDD yollarını tercih eden katılımciların cinsiyet oranları birbirine yakındır. Çalışmada 21-25 yaş aralığında katılımcıların yoğunlukta olduğu görülmektedir. Gelir durumlarına bakıldığında 300-2000 TL gelir elde eden katılımcıların yoğunlukta $(\% 81,5)$ olduğu gözlenmektedir.

Tablo 2. Katılımcıların Demografik Özellikleri

\begin{tabular}{|c|c|c|c|c|c|c|c|}
\hline \multicolumn{2}{|c|}{ Demografik Özellikler } & \multirow{2}{*}{$\begin{array}{c}\text { Siklıkları } \\
189\end{array}$} & \multirow{2}{*}{$\begin{array}{c}\begin{array}{c}\text { Yüzde } \\
(\%)\end{array} \\
47,2\end{array}$} & \multicolumn{2}{|c|}{ Demografik Özellikler } & \multirow{2}{*}{$\begin{array}{c}\text { Siklıkları } \\
8\end{array}$} & \multirow{2}{*}{$\begin{array}{c}\begin{array}{c}\text { Yüzde } \\
(\%)\end{array} \\
2,0\end{array}$} \\
\hline Cinsiyet & Bayan & & & \multirow[t]{6}{*}{ Yaş } & $15-20$ & & \\
\hline & Erkek & 211 & 52,8 & & $21-25$ & 221 & 55,2 \\
\hline \multirow{5}{*}{$\begin{array}{l}\text { Eğitim } \\
\text { Durumları }\end{array}$} & İlköğretim & 63 & 15,8 & & $26-35$ & 67 & 16,8 \\
\hline & Lise & 157 & 39,2 & & $36-45$ & 74 & 18,5 \\
\hline & Üniversite & 145 & 36,2 & & $46-55$ & 19 & 4,8 \\
\hline & \multirow{2}{*}{$\begin{array}{l}\text { Yüksek Lis ve } \\
\text { Doktora }\end{array}$} & \multirow[t]{2}{*}{35} & \multirow[t]{2}{*}{8,8} & & $56+$ & 11 & 2,8 \\
\hline & & & & \multirow[t]{7}{*}{ Meslek } & Öğretmen & 7 & 1,8 \\
\hline \multirow{6}{*}{$\begin{array}{l}\text { Gelir } \\
\text { Durumu }\end{array}$} & $300-500$ & 108 & 27,0 & & Ev Hanımı & 29 & 7,2 \\
\hline & $501-1000$ & 103 & 25,8 & & Doktor & 49 & 12,2 \\
\hline & $1001-2000$ & 115 & 28,8 & & Hemșire & 41 & 10,2 \\
\hline & $2001-3000$ & 33 & 8,2 & & Memur & 46 & 11,5 \\
\hline & \multirow[t]{2}{*}{ 3001-üstü } & \multirow[t]{2}{*}{41} & \multirow[t]{2}{*}{$\frac{0,2}{10,2}$} & & İşçi & 44 & 11,0 \\
\hline & & & & & Mühendis & 184 & 46,0 \\
\hline \multicolumn{2}{|l|}{ TOPLAM } & 400 & 100 & \multicolumn{2}{|c|}{ TOPLAM } & 400 & 100 \\
\hline
\end{tabular}

\section{Verilerin Analizi}

TCDD için 5 boyuttan oluşan ölçeğin güvenilirliğini test etmek için Cronbach Alpha katsayısı kullanılmıştır. Alpha (Cronbach) katsayısı, TCDD'de kullanılan Servqual ölçeğinin beklenti ve algı bölümündeki tüm boyutlar için ayrı ayrı hesaplanmıştır. Algı bölümündeki Cronbach Alfa değeri 0,891, Beklenti bölümünde ise 0,902 bulunmuştur. Bu değer çalışmanın güvenirliğini ispatlamaktadır(Hair et al., 1998).

Katılımcıların demografik özelliklerinin hizmet kalitesi boyutlarıyla olan ilişkilerinin değerlendirilmesine ilişkin analiz sonuçları aşağıdaki tablo 4-5-6'da verilmiştir.
Tablo 3. Güvenirlik Analizi Sonucu

\begin{tabular}{|l|l|c|c|}
\multicolumn{4}{|c}{ İşlenen Vaka Özeti } \\
\hline \multirow{3}{*}{ Durum } & Geçerli & N & $\%$ \\
\cline { 2 - 4 } & Hariç & 0 & 100 \\
\cline { 2 - 4 } & Toplam & 400 & 0 \\
\hline
\end{tabular}

Güvenirlik İstatistiği(Alg1)

\begin{tabular}{|c|c|}
\hline $\begin{array}{l}\text { Cronbach's } \\
\text { Alpha }\end{array}$ & $\mathrm{N}$ of Items \\
\hline, 891 & 28 \\
\hline
\end{tabular}

Güvenirlik İstatistiği (Beklenti)

\begin{tabular}{|r|r|}
\hline $\begin{array}{l}\text { Cronbach's } \\
\text { Alpha }\end{array}$ & N of Items \\
\hline 0,902 & 28 \\
\hline
\end{tabular}


Tablo 4. Hizmet Kalitesi Boyutları Servqual Skorları ve Cinsiyet Arasındaki Bağımsız T Testi Sonuçları

\begin{tabular}{|c|c|c|c|c|c|c|}
\hline & \multicolumn{2}{|c|}{$\begin{array}{l}\text { Varyansların } \\
\text { Eşitliği için } \\
\text { Levene'nin Test }\end{array}$} & \multicolumn{3}{|c|}{$\begin{array}{c}\text { Ortalamaların Eşitliği için } \\
\text { T-testi }\end{array}$} \\
\hline & & $\mathrm{F}$ & Sig & $\mathrm{t}$ & $\overline{\mathrm{Df}}$ & $\begin{array}{l}\text { Sig } \\
\text { (2-tailed) }\end{array}$ \\
\hline \multirow[t]{2}{*}{ Fiziksel } & Varsayılan Eşit Varyanslar & \multirow[t]{2}{*}{45,748} & \multirow[t]{2}{*}{, 000} & $-3,507$ & 398 &, 001 \\
\hline & Varsayılmayan Eşit Varyanslar & & & $-3,568$ & 382,052 & ,000 \\
\hline \multirow[t]{2}{*}{ Güvenirlik } & Varsayılan Eşit Varyanslar & \multirow[t]{2}{*}{6,734} & \multirow[t]{2}{*}{$\overline{, 010}$} & ,417 & 398 & ,677 \\
\hline & Varsayılmayan Eşit Varyanslar & & & ,415 & 380,507 & ,679 \\
\hline \multirow[t]{2}{*}{ Teminat } & Varsayılan Eşit Varyanslar & \multirow[t]{2}{*}{1,706} & \multirow[t]{2}{*}{,192 } & ,765 & 398 & ,445 \\
\hline & Varsayılmayan Eşit Varyanslar & & & ,767 & 396,817 & ,443 \\
\hline \multirow[t]{2}{*}{ Güven } & Varsayılan Eşit Varyanslar & \multirow[t]{2}{*}{4,770} & \multirow[t]{2}{*}{, 030} & 1,307 & 398 & $\overline{1,192}$ \\
\hline & Varsayılmayan Eşit Varyanslar & & & 1,303 & 386,666 & 193 \\
\hline \multirow[t]{2}{*}{ Heveslilik } & Varsayılan Eşit Varyanslar & \multirow[t]{2}{*}{0,50} & \multirow[t]{2}{*}{,824 } & -810 & 398 & ,419 \\
\hline & Varsayılmayan Eşit Varyanslar & & & -809 & 392,528 & ,419 \\
\hline
\end{tabular}

Tablo 5. Fiziksel Boyut ile Cinsiyet Arasında Yapılan Tek Yönlü Varyans Analizi

\begin{tabular}{|l|l|l|l|c|}
\hline \multicolumn{2}{|c|}{} & $\mathrm{N}$ & Ortalama & Standart Sapma \\
\hline Fiziksel & Bayan & 211 & 2,7609 &, 74536 \\
\cline { 2 - 5 } & Bay & 189 & 2,5714 &, 83114 \\
\hline
\end{tabular}

Algılanan hizmetin kalite boyutlarının cinsiyetlere göre anlamlı bir farklılığın olup olmadığının belirlenmesi için yapilan t-Testi'nde, Levene's Test sonucunun varyanslarının eşit olmadığı görülmüştür. Bu durumda varyansların eşit olmadığı satırdaki değerler incelendiğinde
$\mathrm{P}=0,000$ olmasinda dolayı bayanlar ve erkekler arasında Hizmet Kalitesinin Fiziksel boyutunun algilanma düzeyleri açısından fark vardır. Yapılan analiz sonuçlarına göre, bayanların erkeklere göre verilen hizmetin fiziksel boyutunu daha çok önemsediği belirlenmiştir.

Tablo 6. Hizmet Kalitesi Boyutları Servqual Skorları ve Yaş Arasındaki Tek Yönlü ANOVA Testi Sonuçları

\begin{tabular}{|c|c|c|c|c|c|c|}
\hline & & Kareler Toplamı & $\mathrm{df}$ & $\begin{array}{l}\text { Ortalamaların } \\
\text { Karesi }\end{array}$ & $\bar{F}$ & Sig \\
\hline \multirow[t]{3}{*}{ FİZİKSEL } & Gruplar Arasında &, 106 & 5 &, 021 & 2,715 & 0,20 \\
\hline & Gruplar İçinde & 3,068 & 394 & 0,08 & & \\
\hline & Toplam & 3,173 & 399 & & & \\
\hline \multirow[t]{3}{*}{ GÜVENİRLIKK } & Gruplar Arasında &, 219 & 5 & ,044 & 5,413 & 0,00 \\
\hline & Gruplar İçinde & 3,184 & 394 & 0,08 & & \\
\hline & Toplam & 3,403 & 399 & & & \\
\hline \multirow[t]{3}{*}{ HEVESLİLİK } & Gruplar Arasında &, 027 & 5 & ,005 & ,969 & ,436 \\
\hline & Gruplar İçinde & 2,222 & 394 &, 006 & & \\
\hline & Toplam & 3,249 & 399 & & & \\
\hline \multirow[t]{3}{*}{ TEMINAT } & Gruplar Arasında &, 028 & 5 & ,006 & ,862 &, 507 \\
\hline & Gruplar İçinde & 2,584 & 394 & 0,07 & & \\
\hline & Toplam & 2,612 & 399 & & & \\
\hline \multirow[t]{3}{*}{ EMPATİ } & Gruplar Arasında &, 125 & 5 &, 025 & 2,375 & 0,38 \\
\hline & Gruplar İçinde & 4,142 & 394 & 0,11 & & \\
\hline & Toplam & 4,267 & 399 & & & \\
\hline
\end{tabular}


Tablo 7. Hizmet Kalitesi Boyutları Servqual Skorları ve Eğitim Arasındaki Tek Yönlü ANOVA Testi Sonuçları

\begin{tabular}{|c|c|c|c|c|c|c|}
\hline & & Kareler Toplamı & $\mathrm{df}$ & $\begin{array}{c}\text { Ortalamaların } \\
\text { Karesi }\end{array}$ & $\bar{F}$ & Sig \\
\hline \multirow[t]{3}{*}{ FİZIKSEL } & Gruplar Arasında & ,098 & 3 &, 033 & 4,195 &, 006 \\
\hline & Gruplar İçinde & 3,076 & 394 & 008 & & \\
\hline & Toplam & 3,173 & 399 & & & \\
\hline \multirow[t]{3}{*}{ GÜVENİRLİK } & Gruplar Arasında & 057 & 3 & 019 & 2,268 & 0,80 \\
\hline & Gruplar İçinde & 3,345 & 394 & ,008 & & \\
\hline & Toplam & 3,403 & 399 & & & \\
\hline \multirow[t]{3}{*}{ HEVESLİLİK } & Gruplar Arasında & ,162 & 3 & 054 & 10,229 &, 000 \\
\hline & Gruplar İçinde & 2,087 & 394 & 005 & & \\
\hline & Toplam & 2,249 & 399 & & & \\
\hline \multirow[t]{3}{*}{ TEMINAT } & Gruplar Arasında & 0,73 & 3 &, 024 & 3,770 & 011 \\
\hline & Gruplar İçinde & 2,540 & 394 & 006 & & \\
\hline & Toplam & 2,612 & 399 & & & \\
\hline \multirow[t]{3}{*}{ EMPATİ } & Gruplar Arasında &, 178 & 3 & 059 & 5,763 &, 001 \\
\hline & Gruplar İçinde & 4,088 & 394 &, 010 & & \\
\hline & Toplam & 4,267 & 399 & & & \\
\hline
\end{tabular}

Tablo 6'da görüldüğü gibi katılımcıların yaşları ile verilen hizmet kalite boyutları arasında yapılan Tek Yönlü ANOVA Testi sonuçlarına göre, 0,05 anlam düzeyinde güvenirlik boyutunda istatistiksel olarak anlamlı bir farklılık bulunmuştur.

Hizmetin kalitesi boyutları ile katılımcıların eğitim durumları arasında anlamlı bir farklılığın olup olmadığının belirlenmesi için yapılan Tek yönlü ANOVA testi sonuçlarına göre, fiziksel, heveslilik ve empati boyutlarında 0,01 , teminat boyutunda 0,05 anlamlılık düzeyinde istatistiksel olarak bir farkın olduğu belirlenmiştir.

TCDD yolları müşterilerinin hizmet kalitesi boyutlarına verdikleri önem derecelerinin belirlenmesi için yapılan araştırmada, en önemli görülen boyutun güvenirlik boyutu, en düşük boyutun ise fiziksel görünüm olduğu belirlenmiştir. Diğer boyutların önem sıralamass heveslilik, teminat ve empati olarak bulunmuştur. Sonuçlar Tablo 8'de verilmektedir.
Araştırma sonucunda, TCDD için ortalama fark esaslı servqual sonucu -1,2545 olarak bulunmuştur( Bknz Tablo 10). Sonucun negatif olması, müşteri beklentilerinin karşılanmadığı, dolayısıyla müşterilerin hizmetlere yönelik kalite algısının düşük olduğu anlamına gelmektedir. Bu da TCDD'den hizmet almış olan müşterilerin hizmet kalitesi açısından memnun olmadıkları anlamına gelmektedir.

Tablo 9 'dan da görüldüğü gibi tüm hizmet kalitesi boyutları negatif çıkmıştır. Ancak TCDD’nın teminat ve empati kalite boyutlarında müşterileri yüksek derecede memnun etmedikleri görülmektedir. Servqual skorlarından en iyi sonucun fiziksel görünüm boyutuna ait olduğu görülmektedir.

TCDD'de gerçekleştirilen yeniden yapılanma çalışmalarının hizmet kalitesinde bir gelişme sağlayıp sağlamadığının belirlenmesi aşamasında 2004 yılında Poyraz, Taşkın ve Kara tarafından yapılan "Demiryolları İşletmesinde Müşteri Tatmininin Ölçülmesi ve

Tablo 8. Kalite Boyutlarııın Önem Derecelerine Göre Ağırıklandırılması

\begin{tabular}{|l|c|c|c|c|}
\hline Boyutlar & $\mathrm{N}$ & Otalama & Std. Sapma & $\begin{array}{c}\text { Std.Hata } \\
\text { Ortalamas1 }\end{array}$ \\
\hline Fiziki Görünüm & 400 &, 1503 &, 08918 &, 00446 \\
\hline Güvenirlik & 400 &, 2198 &, 09235 &, 00462 \\
\hline Heveslilik & 400 &, 2145 &, 07508 &, 00375 \\
\hline Teminat & 400 &, 2017 &, 08091 &, 00405 \\
\hline Empati & 400 &, 1953 &, 10341 &, 00517 \\
\hline
\end{tabular}


Tablo 9. TCDD için Hizmet Kalitesi Boyutlarının Ortalamaları ve Algılanan ve Beklenen Kalite Arasındaki Fark

\begin{tabular}{|l|c|c|c|}
\hline Boyutlar & Algilanan Ort & Beklenen Ort & Servqual Ort \\
\hline Fiziki Görünüm & 2,8956 & 4,0864 & $-1,1908^{*}$ \\
\hline Güvenirlik & 2,6532 & 3,9236 & $-1,2704^{*}$ \\
\hline Heveslilik & 2,7643 & 3,9818 & $-1,2175^{*}$ \\
\hline Teminat & 2,8750 & 4,1779 & $-1,3029^{*}$ \\
\hline Empati & 2,7679 & 4,0588 & $-1,2909^{*}$ \\
\hline ORTALAMA & $\mathbf{2 , 8 9 1 2}$ & $\mathbf{4 , 0 4 5 7}$ & $\mathbf{- 1 , 2 5 4 5 *}$ \\
\hline
\end{tabular}

Bir Uygulama” başlıklı çalışmalarının sonuçları değerlendirmeye alınmıştır. Oluşturulan kuramsal çerçevenin ve TCDD işletmesi ile ilgili verilen bilgilerin yanı sıra, anket yöntemi ile TCDD işletmesinde müşteri tatmininin ölçülmesi değerlendirilmiştir. Çalışma 20.08.2003-29.08.2003 tarihleri arasında İzmir-Ankara arasında Mavi tren ile seyahat edenler üzerinde gerçekleştirilmiştir. Uygulamanın yapılmasinda 2004 ve 2010 y1linda kullanılan anket soruları özellikle birbirine yakın ifadeler kullanılarak, Gar binalarının içinde bulunan gerek fiziksel unsurları gerekse bireysel unsurlar dikkate alınmadan sadece tren seyahatları esnasındaki sunulan (Araç, Lokanta, Per- sonel, Tuvaletler, Seyahat güvenliği, Zaman, Rahatlık vb) TCDD Yolları Hizmet Kalitelerinin belirlenmesine yönelik olarak hazırlanmıştır. 2004 yılında yapılan çalışmada algılanan hizmet kalitesi genel Servqual skoru -1,7208 olarak bulunmuştur. 2010 yılında yapılan çalışmamızın sonuçlarında ise genel Servqual skoru -1,2545 olarak hesaplanmıştır. Bu noktada algılanan hizmet kalitesinin 0,4663 artığı görülmektedir. \%27'lik bir artış söz konusudur. Boyutlar bazında gerçekleşen gelişmelere bakıldığında en çok gelişmenin empati boyutunda olduğu, en az gelişimin ise güvenirlik boyutunda olduğu görülmüştür.

Tablo 10. 2004 ve 2010 Hizmet Kalitesi Boyutları Servqual Sonuçları Karşılaştırması

\begin{tabular}{|l|c|c|c|}
\hline Boyutlar & $\begin{array}{c}\text { Serqual Ort } \\
(\mathbf{2 0 0 4})\end{array}$ & $\begin{array}{c}\text { Servqual Ort } \\
(\mathbf{2 0 1 0 )}\end{array}$ & $\begin{array}{c}\mathbf{2 0 0 4 - 2 0 1 0} \text { Aras } \\
\text { İyileşmeler }\end{array}$ \\
\hline Fiziki Görünüm & $-1,8475$ & $-1,1908$ & 0.6567 \\
\hline Güvenirlik & $-1,4025$ & $-1,2704$ & 0.1321 \\
\hline Heveslilik & $-1,7288$ & $-1,2175$ & 0,5113 \\
\hline Teminat & $-1,5809$ & $-1,3029$ & 0,27 \\
\hline Empati & $-2,0445$ & $-1,2909$ & 0,75 \\
\hline ORTALAMA & $\mathbf{- 1 , 7 2 0 8}$ & $\mathbf{- 1 , 2 5 4 5}$ & $\mathbf{0 , 4 6 6 3}$ \\
\hline
\end{tabular}

\section{Sonuçlar ve Öneriler}

$\mathrm{Bu}$ çalışma ile, Reschethaler (1996) 'in "The information revolution and the New Public Management" adlı çalışmasında "yeniden yapılanma sürecinde yönetimin başarısı, tüketici tatmini tabanında ölçülmektedir" (Reschenthaler, 1996:133) ve Donnelly ve arkadaşlarının (1996) hizmet kalitesi ile vatandaş tatmini birbirlerinin yerine kullanılabileceği (Reeves ve ark, 1995:63) bilgisi temelinde, yeniden yapılanma sürecinde olan TCDD yollarının, 2004 ve 2010 yılı hizmet kalitesi değerlerinin kıyaslanması ile yönetimin başarısı değerlendirilmiştir.

Değerlendirme sonuçlarında, hizmet kalitesinin boyutları olan fiziki görünüm, güvenilirlik, isteklilik, teminat ve empati Servqual fark esaslı ölçeğine göre incelenmiştir. Sonuçlar müşterilerin genel olarak TCDD için beklediklerinden daha az hizmet bulduklarını ortaya koymuştur. Özellikle, güvenilirlik, empati ve teminat boyutlarında beklenen ile algılanan hizmet kalitesi ortalama skorları arasındaki fark, diğer boyutlardan daha fazladır. Ancak sevindirici olan algılanan hizmet kalitesinin yıllar içinde gelişme göstermesidir. 2004 ve 2010 yıllarında yapılan TCDD yolları hizmet kalitesi ölçüm sonuçları kıyaslandığında, kalitenin \%27 oranında artığ1 görülmektedir. Bu gelişmeye en çok fiziki görünüm ve empati boyutlarındaki iyileşmelerin neden olduğu belirlenmiştir. TCDD yollarına 2004 yılında yapılan yatırım miktarı 383.300.302 TL iken, 2010 yılında bu yatırımın yakla- 
şık 3 kat artarak 1.313.173.060 TL ulaştığı görülmektedir (www.tcdd.gov.tr). Yapılan bu iyileştirme yatırımlarının sunulan Hizmet Kalitesi üzerinde olumlu bir katkısının olduğu söylenebilir.

Ek olarak, katılımcıların demografik özelliklerinden cinsiyet ve yaş ile algılanan hizmet kalite boyutları arasında anlamlı bir farklılık olduğu tespit edilmiștir. Buna göre bayan müşterilerin fiziksel görünüm boyutuna daha çok önem verdiği belirlenmiştir. Yine demografik özelliklerden olan müşterilerin yaşları ile boyutlar arasında, 21-25 yaş arasında olan müşterilerin güvenirlik boyutunu diğer yaş gruplarından olan müşterilere göre daha iyi buldukları sonucuna varılmıştır. Müşterilerin eğitim durumları ile fiziksel görünüm, heveslilik ve empati boyutları arasında bir ilişkinin olduğu belirlenmiştir. Müşterilerce genel hizmet kalitesi boyutlarının önem derecelerinin sıralanması istendiğinde, en önemli boyutun Güvenirlik boyutu olduğu, diğer boyutlara göre önem derecesi en düşük boyutun ise Fiziksel Görünüm olduğu ortaya çıkmıştır. Fakat 2004 ve 2010 yılında yapılan çalışmaların kıyaslanması ile elde edilen değerlerin farklı oluşunun birçok nedeni de olabilir. 2004 ve 2010 y1lında yapılan çalışmalarda kullanılan ölçeklerin benzer oluşları, hizmet sunumunda 2004 yılında kullanılan teknoloji ile 2010 yılında kullanılan teknolojinin farklılığı, çalışmada uygulamanın yapıldığı örneklem grubunun farklılığı, algılardaki farklılıkları ortaya çıkarmış olabilir.

Çalışmanın tüm sonuçları değerlendirildiğinde, TCDD yolları yönetiminin, 2004 yılı ile 2010 yılı arasındaki yeniden yapılanma sürecinde başarılı olduğu söylenebilir. Yalnızca, TCDD yolları müşterilerinin özellikle teminat ve empati boyutlarında daha yüksek tatminsizliği söz konusu olduğundan, hizmet kalitesi gelişmesi için yapılacak yatırımların bu alanlara tahsis edilmesi ve çalışanların süreçlerle ilgili daha bilgili ve nazik olması ve müşterilerde güven duygusu uyandırabilme becerileri ile empati kurma konusundaki becerilerin kazandırılması konusunda eğitim çalışmalarına katılımlarının sağlanması önerilebilir. Müşteri tatminin ölçülmesi yoluyla TCDD için hizmet kalitesinin değerlendirilmesi kurumun stratejik planlarının hazırlanmasında önemli bir araç olabilir. Özellikle bu çalışmanın ışığı altında bundan sonraki yatırımların tahsisi tekrar değerlendirilebilir.

\section{Kaynakça}

Alakavuk, Elif. (2007). "Hizmet Kalitesi Kavramlar, Yaklaşımlar ve Uygulamalar”, Ed. Akbaba, A., Tavmergen, İ.G., Akan, P., Gümüşoğlu, Ş., Detay Yayincilık, Ankara

Anderson. Elizabeth A., (1995)."Measuring Service Quality at a University Health Clinic", International Journal of Health Care Quality Assurance, Vol.8 No.2, 1995, Pp. 32-37

Anderson. Elizabeth A., Zwelling, L.A.,(1996). "Measuring Service Quality at the University of Texas M.D. Anderson Cancer Center", International Journal of Health Care Quality Assurance, Vol.9 No.7, Pp. 9-22

Aydin, Şule. (2007). "Hizmet Kalitesi Kavramlar, Yaklaşımlar ve Uygulamalar”, Ed. Akbaba, A., Tavmergen, İ.G., Akan, P., Gümüşoğlu, Ş., Detay Yayınc1lik, Ankara

Babakus, Emin\& Mangold, Glynn,W. (1992). Adapting the Servqual Scale to Hospital Services: An Empirical Investigation, Health Services Research, 26(6),768-786.

Beugre, C. D, (1998). Implementing business process reengineering: The role of organizational justice. The Journal of Applied Behavioral Science,34. 3, s.347-360.

Bektaş B. (2005). “Türkiye’nin Hizmet Sektörü İhracatı ve Geliştirilmesine Yönelik Öneriler", İgeme Raporu, www. İgeme. Org.Tr/Tur/ Pratik/ Hizmetson Pdf17.10.2006

Brown, S.W, Gummesson, E., Edvardsson, B., \& Gustavsson, B. (Eds).(1991). Service Quality: Multidisciplinary and Multinational Perspectives, Lexington: Lexington Books

Carman. James, (1990). “ Consumer Perceptions of Service Quality: An Assessment of the Servqual Dimensions", Journal of Retailing, Vol: 66 No.1, Pp. 33-55

Caruana, Albert, \& Pitt, Leyland.(1997). Intqual-An Measure of Service Quality and the Link Between Service Quality and Business Performance, European Journal of Marketing, 31(8), 604-616 
Coşkun, R.,(2001). Stratejik Endüstrisi Analizi İçin Porter'n Beș Güç Modelinin KOBİ'lere Uygulanması: Adapazarı Örneği, 9.Ulusal Yönetim ve Organizasyon Kongresi, İstanbul

Cronin, Joseph ve Taylor Steven (1992). "Measuring Service Quality: A Reexamination and Extension", Journal of Marketing, Vol.56,No.3,pp. 55-68

Çetin, C. (1996). Yeniden Yapılanma, Girişimcilik, Küçük ve Orta Boy İşletmeler ve Bunların Özendirilme$s i$, Der Yayınları, 202, İstanbul.

Davis, J and Mehta, K. T.(1997). Reengineering a school of business of the future: A mission/vision model for higher education in transformational times. S.A.M. Advanced Management Journal, 62. 2 . s. 8-15.

Dinçer, Ömer. (1998). Stratejik Yönetim ve İşletme Politikası, 5. Baskı, Beta Yayın, İstanbul

Donnelly, J and Jim, G.,(1996). "Why Should Local Goverment Show an Interest in Service Quality?". The TQM Magazine, Vol:8, Number 5, s. 32-38.

Gulledge, T. R., Sommer, J and Rainer, A.,(2002). Business Process Management Public Sector Implications, Business Process Management Journal, Vol.8/4, 364

Hair,J., Anderson,E.R., Tatham,L., William,C.B.(1998). Multivariate Data Analysis with Readings, Fifth Edition, Prentice Hall International Inc.

Halachmi, A and Bovaird, T.,(1997). Process Reengineering in the Public Sector: Learning Some Private Sector Lessons, Tehnovation. Vo.17, Issue.5, ss.227-235.

Hammer,M., Champy.J., (1993). Reengineering the Corporation: A Manifesto for Business Revolution., Harper Collins, London.

James Y. L. Thong, Chee-Sing Yap, Kin-Lee Seah., (2000). Business Process Reengineering in the Public Sector: The Case of the Housing Development Board in Singapore. Journal of Management Information Systems.Vol. 17(1): 245-270.

Kilbourne, William., Duffy,Ann.,Duffy Micheal and Giarchi, George.(2004). "The Applicability of Servqual in Cross-National Measurements of HealthCare Quality", Journal of Service Marketing, Vol. 18, N.7, Pp.524-533
Kotler, P.,(1980). Marketing Management. PowerPoint by Milton M. Pressley, University of New Orleans.

Le Blanc, G., Nguyen, N.(1988). Customers'perceptions of Sq in Financial Institutions, International Journal of Bank Marketing, 6(4), Pp: 7-18

Lee,S.,Kim,Y.,Hemmington, N., Yun, D., (2004). "Competative Service Quality Improvement: A Case Study in the Fast Food Industry", Food Service Technology, Blackwell Publishing, S. 75-84

Li, M. \& Yang, J. B. (2003). A Decision Model For SelfAssessment of Business Process Based on the Efqm Excellence Model, International Journal of Quality And Reliability Management, 20(2), Pp: 164-188. Doi: 10.1108/02656710310456608

Libbey, M. G.,(1994). Reengineering Public Innovation. Public Performance and Management Review, Vo.18, Issue.2, p.163.

MacAdam, R \&Mitchell, N (1998). Development of a Business Process Re-engineering Model Applicable to The Public Sector. Total Quality Management and Business Excellence, Vol.9/45, pp. 160-163G

MacNulty.,(2002). Quality, Reliability and Maintenance.QRM 2002, Wiley Publisher, ISBN:97818605833698

Mangold,W.G.\&Babakus,E.,(1991). Service Quality: The Front Stage vs. The Back Stage Perspective, The Journal of Services Marketing, 5(4), Pp: 59-70

Mihyar, H.,(2007). Business Progress Reengineering in UAE Public Sector: A Naturalization and Residency Case Study. Business Progress Management Journal, Vol. 13, Issue.5, pp. 707-727.

Mihyar, H., AlAmeed, H and Samak, M.,(2007). Business Process Reengineering in UAE Public Sector: A Town Planning Case Study. Business Process Management Journal, Vol.3, Issue.3, pp. 348-378.

Mucuk,İsmet. (1994). “Pazarlama İlkeleri”,Der Yayınları, 6. Baskı, İstanbul

Ongaro, E,.(2004). Process Management in the Public Sector: The Experience of One-Stop Shop in Italy. The International Ournal of Public Sector Management, Vol.17, Issue.1, pp.81-107. 
Özer, Pınar ve Özdemir Pınar.,(2007). Hizmet Kalitesi Kavramlar, Yaklaşımlar ve Uygulamalar, Ed. Akbaba, A., Tavmergen, İ.G., Akan, P., Gümüşoğlu, S., Detay Yayıncilık, Ankara

Özkul, Emrah. (2007). "Hizmet Kalitesi Kavramlar, Yaklaşımlar ve Uygulamalar”, Ed. Akbaba, A., Tavmergen, İG., Akan, P., Gümüşoğlu, Ş., Detay Yayincllı, Ankara

Parasuraman. A., Zeithaml, V.A. and Berry, L.L.( 1985). "A Conceptual Model of Service Quality And Its Implecations For Future Research", Journal of Marketing, Vol: 49 No.4, Pp. 41-50

Parasuraman. A., Zeithaml, V.A. and Berry, L.L.(1988). "Servqual: A Multiple-Item Scale For Measuring Consumer Perceptions of Service Quality", Journal of Retailing, Vol: 64 No.1, Pp. 12-40

Poyraz, Kemal., Taşkin, E ve Kara, Hakan (2004). Demiryolları İşletmesinde Müşteri Tatmininin Ölçülmesi Ve Bir Uygulama, Anadolu Üniversitesi Sosyal Bilimler Dergisi, Cilt 4, No: 2, Ss: 73-88.

Reeves, C. A, David A.B, Lawrance, R.C., (1995). “Back to the Beginning: What Do Customer Care About in Service Firms??. Quality Management Journal, Vol.3, No. 1,

Peyrot, Mark.,Cooper, Philip., Schnapf, Donald.(1993). "Consumer Satisfaction and Perceived Quality of Outpatient Health Servces", Journal of Health Care Marketing, Vol.13, No. 1, S. 24-33
Reschenthaler, G. B. (1996). “The information revolution and the New Public Management", Journal of PA Research\&Theory, 16, 1:125-144.

Ruhli, E, Treichler, C and Schmidt, S. L, (1995). From business reengineering to management reengineering--a European study. Management International Review. 35. 4,s. 361.

Stoddard, D. B., Jarvenpaa, S. L \& Littlejohn, M., (1996). The Reality of Business Reengineering: Pacific Bell's Centrex Provisioning Process. California Management Review, Vol.38(3), ss.57-76.

Quester, P. ve Romanjuk, S.(1997). "Service Quality in Australian Adversiting Industry: A Methodological Study", The Journal of Service Marketing, Vol. 27, S: $180-188$.

Uyguç, Nermin. (1998). Hizmet Sektöründe Kalite Yönetimi :Stratejik Bir Yaklaşım, 1. Baskı, İzmir,Dokuz Eylül Yayınları

Zaher, A., Mushtag, K and Ishaq, H. M.,(2008). Reengineering The Procedures Progress in a Public Sector Organization : A Case Study. International Bulletin of Business Administration, Vol.3. pp.30-43.

Zeithaml,V.(2000). Sq, Profitability, and The Economic Worth of Costumers: What We Know And What We Need to Learn, Journal of The Academy of Marketing Science, 28(1) ,Pp: 67-85. 